\title{
HIGH STAGE EVENTS AND STREAM BANK EROSION ON SMALL GRAZED PASTURE STREAM REACHES IN THE RATHBUN LAKE WATERSHED, SOUTHERN IOWA, USA
}

\author{
Mustafa Tufekcioglu ${ }^{1 *}$, Thomas M. Isenhart ${ }^{2}$, Richard C. Schultz ${ }^{2}$ \\ $1^{*}$ Faculty of Forestry, Artvin Coruh University, Artvin 08000, Turkey; \\ ${ }^{2}$ Department of Natural Resource Ecology and Management, Iowa State University, Ames, Iowa 50011, USA; \\ *Corresponding Author Mustafa Tufekcioglu: e-mail:mtufekcioglu61@gmail.com;
}

Received September 2019; Accepted October 2019; Published November 2019;

DOI: https://doi.org/10.31407/ijees9424

\begin{abstract}
Stream bank erosion in agricultural landscapes is a major pathway for non-point source sediment and phosphorus loading of receiving waters. Previous studies have shown direct and indirect effects of land use on stream bank erosion, and identified high erosion rates within riparian pastures. One potential impact of agricultural land-use on stream bank erosion is the alteration of stream stage characteristics, including an increase in frequency of high-stage events over short periods of time (forming flash hydrographs). The objective of this study was to assess the relationship between the number of high stream stages and corresponding stream bank soil erosion. The study was conducted in six grazed pasture stream reaches within the Rathbun Lake Watershed, a reservoir on the Chariton River located within the Southern Iowa Drift Plain. The erosion pin method was utilized to measure the change in stream bank erosion in response to differences in the number of high stream-stage events, which were monitored by pressure transducers. The measured seasonal bank erosion rates were correlated with the different stream stages data to assess their impact on stream bank erosion. Based on the different model assumptions, there were generally strong linear relationships between high stage and bank erosion. Approximately $75 \%$ of the variability in stream bank erosion rates was directly linked to the number of high stages/erosive stream flow depths. Conservation practices that reduce these erosion rates will be those that increase soil-water infiltration, reduce the frequency of high stream flow events and increase bank stability through perennial vegetation cover or reducing disturbance within the riparian zone.
\end{abstract}

Keywords: streambank erosion, stage-erosion relationship, grazing pasture system, agricultural small order streams. 